\title{
THE FARMER LIVELIHOOD ASSET ON BANANA FARMING IN EAST JAVA
}

\author{
Dwi Retno Andriani ${ }^{1, *}$, Budi Setiawan ${ }^{2}$, Djoko Koestiono², Abdul Wahib M. ${ }^{2}$ \\ ${ }^{1}$ Post Graduate Program, Faculty of Agriculture, University of Brawijaya, Indonesia \\ ${ }^{2}$ Socio-economics Agriculture Department, Faculty of Agriculture, University of Brawijaya, Indonesia \\ * Corresponding author: dwiretno.ub@gmail.com
}

\begin{abstract}
This research aims to find out and analyze the performance of banana farmers in East Java, from the aspect of livelihood assets, which include human assets, natural, financial, physical, and social. This study using the Sustainable Livelihood Approach method. Results show that the analysis of the sustainable livelihood approach showed that the five assets performance of banana farmers are: $52.53 \%$ for the human asset, $44.70 \%$ for natural assets, $39.53 \%$ for the financial asset, $49.40 \%$ for the physical asset, and $60.27 \%$ for social asset. Banana farmers have a high ability to use social resources and weak in employing the financial asset. It is because banana farmers in the majority use their limited capital. From three regencies, the highest access to the assets is Malang regency, with an average ability to access resources is $51.8 \%$.
\end{abstract}

Keywords: farmers, bananas, farming, livelihood assets

http://dx.doi.org/10.21776/ub.agrise.2020.020.2.6

Received 23 April 2019

Accepted 31 March 2020

Available online 30 April 2020

\section{INTRODUCTION}

Sustainability in banana farming will be seen in the condition of ownership of farmer asset assets in cultivating banana agribusiness. In carrying out livelihoods, the assets needed are not just one type. For this reason, a combination of existing assets will be required to improve people's welfare. The types of assets that are more useful or supportive of one's livelihood are different for each individual.

Each resource has a relationship or association with other resources. Development policies and programs that effectively pay attention to and map precisely which resources are a priority in a program and which resources need to get support. This can be seen from economic development through the assistance of government and private institutions that influence the existence of positive and negative movements.

By strengthening and maximizing farm off-farm activities/marketing of banana cultivation through the banana commodity agribusiness development model that can maximize the integration between asset livelihood factors that can increase the performance of agriculture commodities bananas in East Java competitiveness.

\section{RESEARCH METHODS}

Method for determining the location and time of research

Determination of the research location was done purposively in East Java, especially the largest banana producers in East Java; there are Malang, Lumajang, and Banyuwangi. For Malang Regency covering the area of Dampit, Bantur, and Kasembon. Lumajang Regency is Senduro, and Banyuwangi Regency is the Sempu, Genteng, and Siliragung.

The selection of research locations is based on the consideration that this location is the largest banana producing area in East Java. These three districts produce horticulture products in the form of banana commodities in their respective regions, and still have the opportunity to get higher productivity in developing local banana commodities. With these conditions, they can see how they are implementing strategic management in the face of increasing market demand and developing sustainable banana agribusiness. 


\section{Determination Method of Respondents}

The method of determining respondents in this study used the survey method. The survey is a research method using a questionnaire as an instrument for collecting data. The aim is to obtain information about a number of respondents who are considered to represent specific populations such as representatives of banana farmers and banana agribusiness in East Java. Respondents in this study were banana farmers in Malang, Lumajang, and Banyuwangi use as key information (key informants).

\section{Method of Collecting data}

\section{Primary Data}

Primary data is obtained directly from various districts in East Java through interviews by communicating directly with key informants and data from questionnaires. Data taken include data relating to research interests, such as farmer groups with their integration.

\section{Secondary Data}

This data was obtained from company owners and various agencies related to research, such as the Subdistrict office, East Java Industry and Trade Office, and the East Java Provincial Agriculture Office. Secondary data was also taken from various scientific libraries that supported the research topic as a basis or guidance in supporting primary data and complete report writing of data obtained.

While the research data collection method is carried out by several methods, including the following:

\section{Observation}

Observation is a method or mechanism for collecting data through a process of observation of the behavior of subjects (people), objects (objects), or certain events without any communication activities to the parties under study. In this study, the observations made by researchers were passive and active by making observations directly and communicating with respondents.

In this study, the observation was preceded by an introduction to the area, population, and respondents studied, looking at the habits of respondents in banana farming, describing, analyzing, and interpreting everything related to banana agribusiness activities.

\section{Focus Group Discussion (FGD)}

Focus Group Discussion (FGD) aims to get information from respondents directly that comes from the discussion process and focuses only on certain groups and is carried out in several regions in the district that is the location of the study. In
Malang Regency, FGD was conducted in Bantur, Dampit, and Kasembon areas. Whereas in Lumajang Regency, FGD was conducted in Senduro, and Banyuwangi Regency was conducted in the areas of Genteng and Songgon. Before the discussion, all participants filled out a form that contained demographic data on each FGD participant and also general information related to banana agribusiness activities and set up a discussion on the research topic.

The FGD was conducted with the Exploration Question with more in-depth questions about the core of the discussion held in relation to banana agribusiness activities in the local area.

\section{Interview}

According to Singarimbun and Effendi (1995) in Assidiq (2011), interviews are a way of getting information by asking questions directly to respondents. Interviews were carried out with questionnaires, namely a list of questions to obtain answers from respondents, which included data relating to the research title.

Interviews in the form of in-depth interviews are ways to get information by giving questions directly to respondents who can provide complete and indepth information related to research.

\section{Documentation}

Documentation is one of the tools for secondary data retrieval, which is taking data from existing data in accordance with the overall research. Secondary data in this study were taken from the Ministry of Agriculture, East Java Central Bureau of Statistics, Department of Agriculture of Malang Regency, Lumajang and Banyuwagi, BPS of Malang Regency, Lumajang, Banyuwangi and from related agencies.

Sugiyono (2011) revealed that the document is a record of events that have passed. Examples of documents can be in the form of writing, pictures, or monumental works from someone. Documents in the form of writings such as diaries, life history, stories, biographies, regulations, policies. The documents are in the form of photos, live images, sketches, and others.

\section{Data Analysis Method}

A study requires data analysis and interpretation that aims to answer research questions in revealing certain social phenomena. The method chosen to analyze the data must be in accordance with the research pattern and the variables to be studied. The method of analysis in this study is descriptive and quantitative. In addition, the Sustainable Livelihood Approach (SLA) method is also used to analyze the 
ability of banana farmers to access natural, human, financial, physical, and social resources.

\section{Sustainable Livelihood Approach}

Data analysis was performed using descriptive statistical methods. Tables, diagrams, and frequency distributions will be used to present data. Then the data is interpreted and described descriptively so that it can be more meaningful. Scoring techniques are used to measure the assets that are most dominantly owned by the community, which are then visualized using the pentagon radar diagram.

Each variable is then weighted; the weight measure is verified to the community to adjust to the actual conditions at the research location. From each answer in the next questionnaire, a score is given. The results of measuring assets used by farmers in managing banana agribusiness are presented in the pentagon diagram, so that the most dominant assets can be seen by farmers and comparison between assets. By looking at the pentagon diagram, the forms of intervention that can be done to increase income in livelihood can be planned.

\section{RESULTS AND DISCUSSION}

\section{Banana Farmer Livelihood Assets Analysis in East Java}

Assets include the availability and accessibility of the community towards resources that can support and support community livelihoods. The ability to obtain improved sources of sustainable livelihood strategies include human assets, natural assets, financial assets, physical assets, and social assets. So that the source of livelihood can be seen as a basic asset of the various livelihoods that the individual will build. So that the priority scale of the availability of assets in an area will be different from the other regions, which causes production to also be different in each region.

The results of the calculation of the measurement of the assets of banana farmers are shown in Table 33. The calculation results of the assets used by farmers are then mapped in the form of asset pentagon diagrams. The depiction of the assets of banana farmers will be differentiated in each region. This is done because of the condition of each land, different cultivation handling.

Tabel 1. Asset scores of bananas' farmers

\begin{tabular}{|c|c|c|c|c|c|c|}
\hline \multirow[b]{2}{*}{ No } & \multirow{2}{*}{$\begin{array}{l}\text { Regency/ } \\
\text { Province }\end{array}$} & \multicolumn{5}{|c|}{ Type of Assets } \\
\hline & & Human Asset & Natural Asset & Financial Asset & $\begin{array}{c}\text { Physical } \\
\text { Asset }\end{array}$ & Social Asset \\
\hline 1. & Malang & $58,10 \%(\mathrm{CB})$ & $47,00 \%(\mathrm{CB})$ & $40,15 \%(\mathrm{CB})$ & $48,87 \%(\mathrm{CB})$ & $65,13 \%(\mathrm{~B})$ \\
\hline 2. & Lumajang & $41,50 \%(\mathrm{CB})$ & $43,60 \%(\mathrm{CB})$ & $39,80 \%$ (TB) & $50,80 \%(\mathrm{CB})$ & $44,27 \%(\mathrm{CB})$ \\
\hline 3. & Banyuwangi & $52,40 \%(\mathrm{CB})$ & $41,20 \%(\mathrm{CB})$ & $37,60 \%$ (TB) & $49,07 \%(\mathrm{CB})$ & $66,53 \%(\mathrm{~B})$ \\
\hline 4. & Jawa Timur & $52,53 \%(\mathrm{CB})$ & $44,70 \%(\mathrm{CB})$ & $39,53 \%$ (TB) & $49,40 \%(\mathrm{CB})$ & $60,27 \%(\mathrm{~B})$ \\
\hline
\end{tabular}

The criteria: $\mathrm{STB}=$ Very Poor; $\mathrm{TB}=$ Poor; $\mathrm{CB}=$ Acceptable; $\mathrm{B}=\mathrm{Good}$; $\mathrm{SB}=$ Very Good

Source: Primary data analyzed, 2019

\section{Banana Farmer Livelihood Asset Mapping in Malang Regency}

Figure 10 shows that farmers in Malang Regency are more dominant using social assets. It can be seen from the score of the highest social assets when compared with other assets, which is equal to $65.13 \%$ (B). Social assets include organizations that are followed, FGD (Focus Group Discussion), and harmony. Social assets are a force for cultivating livelihoods through networks and social linkages such as group participation, mutual cooperation, trust and mutually beneficial cooperation (Scoones, 1998).
The lowest score in Malang Regency, which is a financial asset that has a score of $40.15 \%$. Financial assets consist of banana farmers' income, farming capital, loans, and the number of family dependents. The income of banana farmers in the Malang Regency is IDR 1,000,000-1,500,000. The capital of banana farmer farming in Malang Regency is IDR 500,000-1,000,000.

Physical assets are the next lowest assets, which is equal to $48.87 \%$. Physical assets include vehicle ownership, land accessibility, and production facilities. The average vehicle ownership of banana farmers in the Malang Regency is one motorcycle unit. 


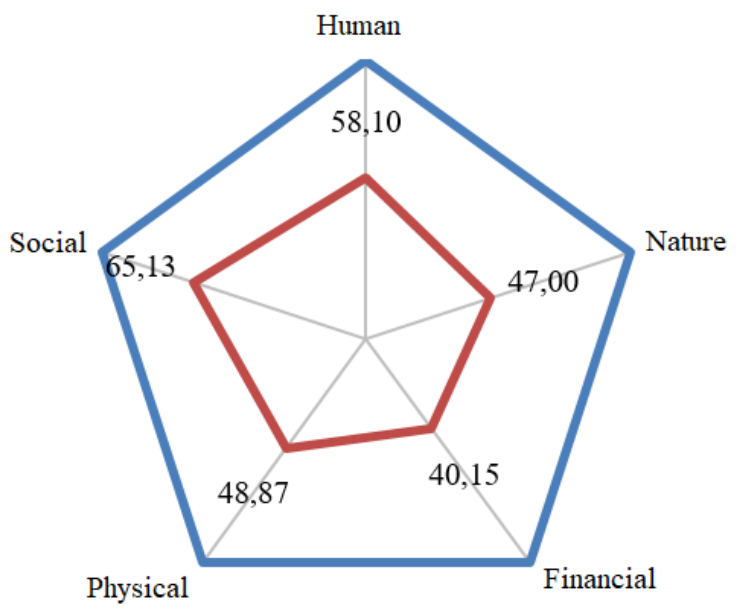

Figure 10. Pentagonal assets of Malang Regency

Land accessibility in Malang Regency is not very good, because access to land cannot be passed by 4-wheeled vehicles. The production facilities owned by banana farmers in Malang Regency amount to 7-10 units. The final sequence of asset use is human assets, which is equal to $58.10 \%$.

Human assets include education, farming experience, number of members who do not work, and farming knowledge and skills. Banana farmers in Malang Regency have an average elementary school education. Experience of farming banana farmers between 16-24 years. Banana farmers have 3 children who do not work. Knowledge and skills of banana farmer farming in class 1 are due to never taking farming training.

\section{Mapping of Banana Farmer Livelihood Assets in Lumajang Regency}

Figure 11 shows that farmers in the Lumajang area more dominant in physical assets. This can be seen from the score of the highest physical assets when compared to other assets, which is equal to $50.80 \%$ (CB). Physical assets include vehicle ownership, land accessibility, and production facilities. The physical assets of Lumajang Regency include relatively easy access to agricultural land; the land is also quite close to the highway, so it is easy to access.

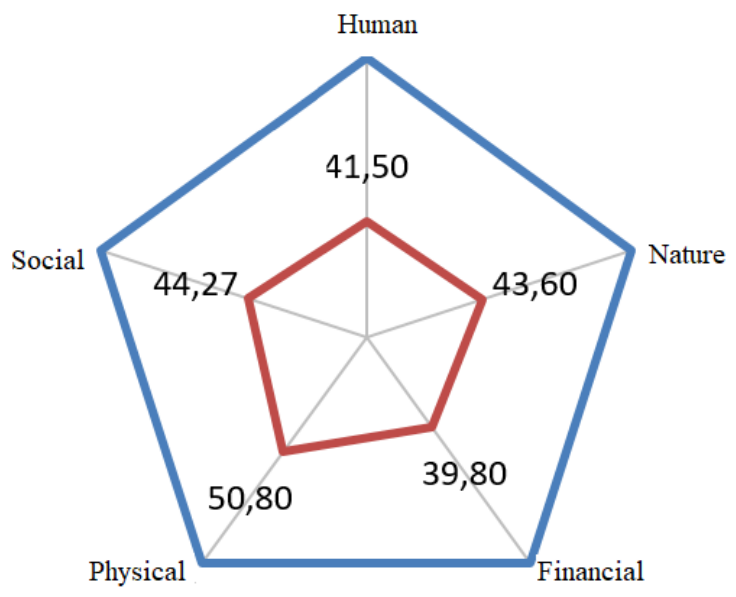

Figure 11. Pentagonal assets of Lumajang Regency

The lowest score in Lumajang, namely financial assets which have a score of $39.80 \%$. Financial assets consist of banana farmers' income, farming capital, loans, and the number of family dependents. The income of banana farmers in the Lumajang Regency is Rp.500,000-1,000,000. The farming capital of banana farmers in Lumajang Regency is $<$ Rp. 500,000. The average loan for banana farmers in Lumajang Regency is <Rp. 500,000. While the average number of dependents in Lumajang banana growers are 2 children. 
Human assets are the next lowest asset, which is $41.50 \%$. Human assets include education, farming experience, number of members who do not work, and farming knowledge and skills. Banana farmers in Lumajang Regency have an average elementary school education. Experience of $<16$ years banana farmer farming. Banana farmers have one child who does not work. Knowledge and skills of banana farmer farming in class 1 are due to never taking farming training.

Natural assets are the next lowest asset, which is $43.60 \%$. Natural assets include the extent of land ownership, use of land area, and farmer productivity capabilities. In the Lumajang Regency area, the average land ownership of banana farmers is $<0.40$ Ha. Banana plants are included in intercropping plants where they are planted together with other plants, one of which is sengon tree.

The final sequence of asset use is social assets, which is $44.27 \%$. Social assets include organization, kinship, focus group discussion. In the Lumajang Regency area, there is no organization in farming. Kinship among fellow farmers is very close, and in the case of focus group discussion, community participation is very low.

\section{Mapping of Banana Farmer Livelihood Asset in Banyuwangi Regency}

In Figure 12, it shows that farmers in Banyuwangi Regency are more dominant using social assets. This can be seen from the score of the highest social assets when compared to other assets, which is equal to $66.53 \%$ (B). Social assets include organizations that are followed, FGD (Focus Group Discussion), and harmony. In the Banyuwangi Regency area, banana farmers follow one organization in farming. Kinship among fellow farmers is very close, and in the case of focus group discussions, community participation is very high.

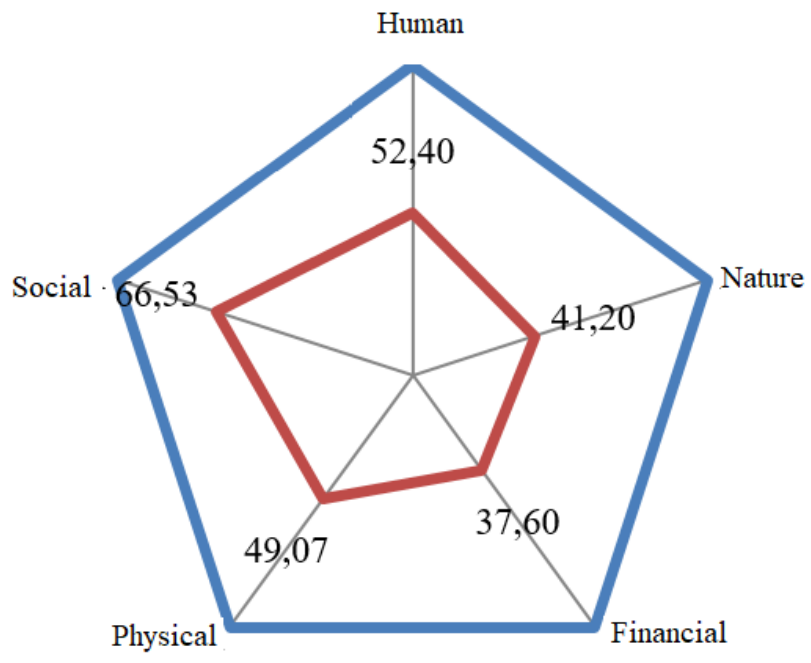

Figure 12. Pentagonal assets of Banyuwangi Regency

The lowest score in the Banyuwangi Regency, which is a financial asset that has a score of $37.60 \%$. Financial assets consist of banana farmers' income, farming capital, loans, and the number of family dependents.

The income of banana farmers in the Banyuwangi Regency is Rp.500,000-1,000,000. The farming capital of banana farmers in the Banyuwangi Regency is $<\mathrm{Rp}$. 500,000. The average loan of banana farmers in the Banyuwangi Regency is $<\mathrm{Rp}$. 500,000. While the average number of dependents of the family of banana farmers in the Banyuwangi Regency is two children. Natural assets are the next lowest asset, which is $41.20 \%$. Natural assets include the extent of land ownership, use of land area, and farmer productivity capabilities. In the Banyuwangi Regency area, the average land ownership of banana farmers is 0.41-0.60 Ha.

Banana plants are included in agroforestry plants which are planted together with other forest plants. Farmer's productivity capability.

Physical assets are the next lowest asset, which is $49.07 \%$. Physical assets include vehicle ownership, land accessibility, and production facilities. The average vehicle ownership of banana farmers in the Banyuwangi Regency area is one motorcycle unit. Accessibility of land in Banyuwangi Regency is not very good, because access to land cannot be passed by wheeled vehicles 4. The production facilities owned by banana farmers in Banyuwangi Regency are 7-10 units. 
The final sequence of asset use is human assets, which is $52.40 \%$. Human assets include education, farming experience, number of members who do not work, and farming knowledge and skills. Banana farmers in the Banyuwangi Regency area have elementary education. Experience of 41 years of banana farmer farming. Banana farmers have three children who do not work. Knowledge and skills of banana farmer farming in class 1 are due to never taking farming training.

\section{Banana Farmers Livelihood Asset Mapping in East Java}

Figure 13 shows that farmers in East-Java Province are more dominant using social assets. It can be seen from the score of the highest social assets when compared to other assets, which is equal to $60.27 \%$ (B).

Social assets include organizations followed, FGD (Focus Group Discussion), and harmony. Based on the three regions in East-Java Province , banana farmers in Banyuwangi Regency participated in one organization in farming, while the other two districts did not follow. The relationship between fellow farmers is very close, and in terms of focus group discussion, community participation is quite high.

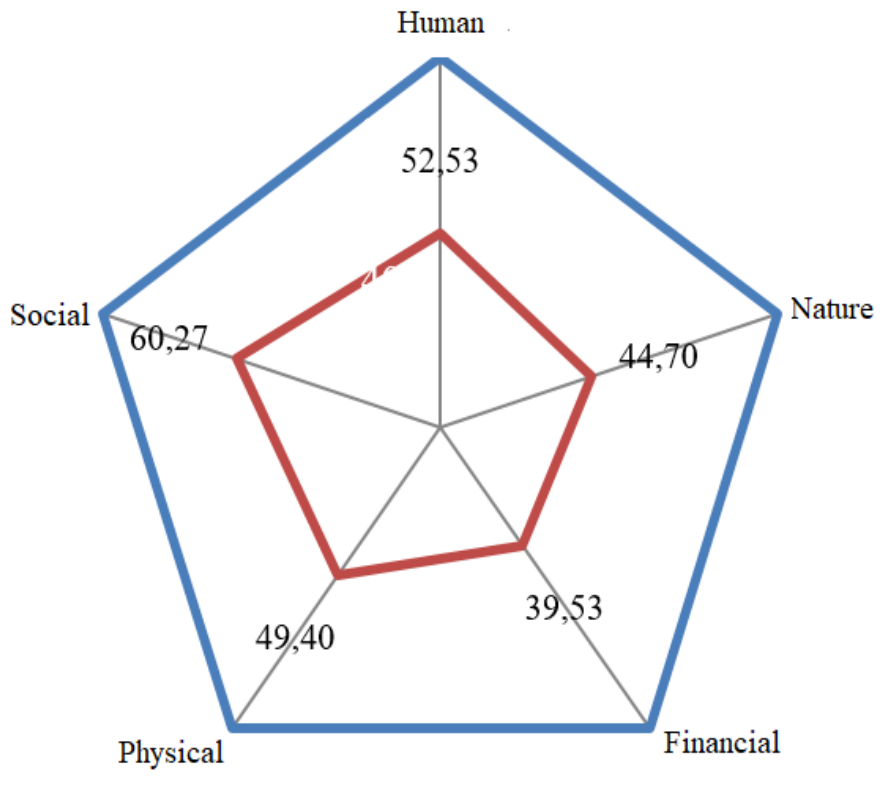

Figure 13. Pentagonal asset of East Java Province

The lowest score in East-Java Province, which is a financial asset that has a score of $39.53 \%$. Financial assets consist of banana farmers' income, farming capital, loans, and the number of family dependents. The income of banana farmers in EastJava Province averages Rp. 500,000-1,000,000. The farming capital of banana farmers in East-Java Province is an average of $<\mathrm{Rp}$. 500,000. The average loan of banana farmers in East-Java Province is an average of $<$ Rp. 500,000. While the average number of dependents of the family of banana farmers in East-Java Province is one child. Natural assets are the next lowest asset, which is $44.70 \%$. Natural assets include the extent of land ownership, use of land area, and farmer productivity capabilities. EastJava Province, the average land ownership of banana farmers is 0.41-0.60 Ha.
Banana plants In East Java province are included in intercropping plants where they are planted together with other plants, such as coffee, sengon, and other forest plants. Farmer's productivity capability

Physical assets are the next lowest asset, which is $49.40 \%$. Physical assets include vehicle ownership, land accessibility, and production facilities. The average vehicle ownership of banana farmers in East-Java Province is 1 motorcycle unit. Accessibility of land in East-Java Province is not very good, because access to land cannot be passed by wheeled vehicles 4 . The production facilities owned by banana farmers in East-Java Province are 7-10 units

The last sequence of asset use is human assets, which is $52.53 \%$. Human assets include education, farming experience, number of members who do not 
work, and farming knowledge and skills. On average, banana farmers in East Java have elementary school education. The experience of banana farmer farming is on average <16 years. Banana farmers have 1 child who does not work. Knowledge and skills of banana farmer farming in class 1 are due to never taking farming training.

\section{CONCLUSION}

The results of the analysis of sustainable livelihood approach showed that the ability of banana farmers to access resources was influenced by 5 assets, namely human assets $52.53 \%$, natural assets $44.70 \%$, financial assets $39.53 \%$, physical assets $49.40 \%$ and social assets of $60.27 \%$. Where banana farmers have a high ability to access social resources and are weak in access to financial resources, because the funding of banana agribusiness, the majority of farmers use their limited capital. Of the three districts that have the highest access to resources, Malang Regency with an average ability to access resources is $51.8 \%$.

\section{REFERENCES}

Adebiyi, A., Banjo, H., \& Regin, O.-O. (2015). Performance of Small and Medium Enterprises in lagos State: The Implications of Finance. Acta Universitas Danubius, 5(8), 72-83.

Adeoye, I. B., Donstop, N. P., Badmus, M. A., \& Amao, I. O. (2011). Price Transmission And Market Integration Of Banana And Plantain In Oyo State, Nigeria. Arpn Jounal of Agriculture and Biological Science, 6(5), 1824.

Akcaoz, H., Ozcatalbas, O., \& Kizilay, H. (2009). Risk management and sustainability in banana production: A case study from Turkey. Journal of Food, Agriculture and Environment, 7(2), 283-294.

Allison, Edward H and Benoit Horemans. 2006. Putting The Principles Of The Sustainable Livelihoods Approach Into Fisheries Development Policy and Practice. Marine Policy 30 (2006) 757-766

Ancok, J. (2012). Psikologi Kepemimpinan dan Inovasi. Jakarta: Erlangga.

Ansyori. (2009). Kriteria Lahan Kesesuaian Lahan untuk Tanaman Pisang Cavendish yang Dikelola secara Intensif di Way Kambas Lampung Timur. Institut Pertanian Bogor.

Barney, J. (1991). Film Resources and Suistained Competitive Advantange. Journal of Management, 1(17), 99-12.
Bungaran, S. (2001). Agribisnis: Paradigma Baru Pembangunan Ekonomi Berbasis Pertanian. Jakarta: Yayasan Mulia Persada Indonesia.

Chambers, Robert \& Gordon R. Conway. (1991)."Sustainable Rural Livelihood: Practical Concepts for The 21st Century." 02 Juli 2012.

Coleman, S. J. (2008). Dasar-Dasar Teori Sosial. Bandung: Nusa Media.

Damsar. (1997). Sosiologi Ekonomi. Jakarta: Raja Grafindo Persada.

David, F. R., \& David, F. R. (2016). Manajemen Strtegik: Suatu Pendekatan Keunggulan Bersaing. Jakarta: Salemba Empat.

Dharmawan, A. H. (2002). Kemiskinan Kepercayaan (The Poverty of Trust), Stok Modal Sosial dan Disintegrasi Sosial. Bogor.

Downey, W. . dan S. P. E. (1992). Manjemen Gribisnis (terjemahan). Jakarta: Erlangga.

Downey, W. D. (2000). Manajemen Agribisnis. Jakarta: Erlangga.

Dullayaphut, P., \& Untachai, S. (2013). Development the Measurement of Human Resource Competency in SMEs in Upper Northeastern Region of Thailand. Procedia Social and Behavioral Sciences, 88, 61-72. https://doi.org/10.1016/j.sbspro.2013.08.481

Enggasari. (2007). meneliti tentang Membangun Kualitas Melalui Strategi Informasi dan supply chain management pada Industri CPO.

Enteding, T., Hadayani, \& Adam, R. (2016). Analisis Pemasaran dan Strategi Pengembagan Komoditi Kedelai di Desa Nipa Kalemon Kecamatan Bualemo Kanupaten Banggai. Sains Dan Teknologi Tandulako, 2(3), 11-24.

Ferdinan, A. . (2002). Structural Equation Modelling dalam Penelitian Manajemen. Semarang: BPUNDIP.

Field, J. (2010). Modal sosial. Yogyakarta: Kreasi Wacana.

Firdaus, M., \& Silalahi, B. G. S. (2008). Posisi bersaing nenas dan pisang indonesia di pasar dunia. Jurnal Agribisnis Dan Ekonomi Pertanian, 1(2), 23-30.

Fitrah, H. (2013). Analisis Pemasaran Agribisnis Lada (Piper Nigrum L) Di Desa Mangkauk Kecamatan Pengaron Kabupaten Banjar Kalimantan Selatan. Zira'ah, 38(3), 28-32.

Friyanto, S., \& Saptana. (2017). Kinerja Agribisnis Komoditas Pertanian: Kemampuan Penciptaan Output, Nilai Tambah dan Keterkaitan antar Sektor (Analisis Komaparasi 
IO tahun 2005 dan 2010). Manajemen Dan Agribisnis, 14(3), 250-263.

Fukuyama, F. (2001). Social Capital: Civil Society and Development. Third World Quarterly.

Gustiani, D., \& Parulian, H. (2009). Analisis Keunggulan Komparatif Dan Kompetitif Kain Tenun Sutera Produksi Kabupaten Garut (Studi Kasus pada Perusahaan PT. Aman Sahuri di Kabupaten Garut Provinsi Jawa Barat). Jurnal Agribisnnis Dan Ekonomi Pertanian, 53, 160. https://doi.org/10.1017/CBO9781107415324. 004

Kamal, S., Ali, A., \& Alam, F. (2014). Socioeconomic status and problems of banana growers in Bangladesh, 1, 91-99.

Kementan. (2017). Kebijakan Pembangunana Pertanian Berkelanjutan.

Kifli, F. W., Mulyo, J. H., Darwanto, D., \& Hartono, S. (2017). Pengaruh Modal Sosial terhadap Permintaan PanganRumahtangga Tani di Provinsi Riau. Manajemen Dan Agribisnis, 14(3), 273-283.

Kock, H., \& Ellström, P. (2011). Formal and integrated strategies for competence development in SMEs. Journal of European Industrial Training, 35(1), 71-88. https://doi.org/10.1108/03090591111095745

Komarek, A. . (2010). The Determinants Of Banana Market Commercialisation in Western Uganda. African Journal of Agricultural Research, 5(9), 775-784.

Krantz, Lasse. (2001). The Sustainable Livelihhood Approach to Poverty Reduction. Swedish: SIDA. 02 Juli 2012.Lambert, D. M., \& Cooper, M. C. (2000). Issues in supply chain management. Industrial Marketing Management, 29(1), 65-83.

Lolowang, I. T. F., Loho, I. A. E., \& Ngangi, I. C. R. (2015). Kajian Kinerja Agribisnis Starwberry Organik Study Kasus Kelompok Tani Kina Kelurahan Rurukan dan Kelompok Tani Agape Kelurahan Rurukan Satu Marlen Meilani Rumengan Dosen Pembimbing :

Miller, C. . (1994). Strategic Planning and Firm Performance: A Synthesis of More Than Decades of Research. Academy of Management Journal, 37(6), 1649-1665.

Mudiarta, K. G. (2009). Jaringan Sosial (Networks) dalam Pengembangan Sistem dan Usaha Agribisnis: Perspektif Teori dan Dinamika Studi Kapital Sosial. Forum Penelitian Agro Ekonomi, 27(1), 1-12. https://doi.org/02164361
Muflikh, Y. N. dan S. (2009). A Review of Supply Chain Management Literature and Its Implication To Develop Agribusiness in Indonesia the Driving Forces of Supply Supply. Agribisnis Dan Ekonomi, 3(2), 104121. Retrieved from http://jesl.journal.ipb.ac.id/index.php/jurnalag ribisnis/article/view/17087/12386

Porter, M. . (1990). The Compeitive Advantage of Nations. New York: Free Press.

Prihatman, K. (2000). Pisang (Musa spp) (No. 21316916669). Pisang. Retrieved from http://www.warintek.ristek.go.id/pertanian/pis ang.pdf

Purnaningtyas, D. P. (2012). Analisis Efisiensi Ekonomi Penggunaan Faktor. Agrista. Universitas Sebelas Maret.

Rahim, A., \& Hastuti, R. R. (2007). Ekonomi Pertanian, Pengantar Teori dan Kasus. Penebar Swadaya.

Ritzer, G., \& Goodman, D. J. (2010). Teori Sosiologi (Dari Teori Sosiologi Klasik sampai Perkembangan Mutakhir Teori Sosial Postmodern). Bantul: Kreasi Wacana.

Rumanti, A. A., \& Syauta, K. J. (2013). Determining Strategies Based on Strategic Position Analysis in Small and Medium Enterprises. International Journal of Information and Education Technology, 3(4), 442-447. https://doi.org/10.7763/IJIET.2013.V3.315

Samsudin. (2005). Manajemen Sumber Daya Manusia. Bandung: Pustaka Setia.

Samuelson, \& Nordhaus. (2002). Mikroekonomi. Jakarta: Erlangga.

Scoones, I., 1998. Sustainable Rural Livelihoods: A Framework for Analysis. IDS Working paper, 72. Brightons.

Simatupang, P., \& Rusastra, I. W. (2004). Kebijakan Pembangunan Sistem Agribisnis Padi.pdf.

Soekarwati. (1995). Analisis Usaha tani. Jakarta: UI Press.

Soekarwati. (2007). e-AGRIBISNIS : TEORI DAN APLIKASINYA. In Seminar Nasional Aplikasi Teknologi Informasi (p. 25).

Sugiyono. (2002). Metode Penelitian Administrasi. Bandung: CV Alfabeta.

Suvittawat, A. (2014). Thailand â€TM s Banana Supply Chain Management: Export Success Factors. International Journal of Management Sciences and Business Research, 3(10), 22268235 . 
Vijayakumar, S. (2013). the Status of Small and Medium Enterprises and Promotions for Their Growth in Srilanaka. International Journal on Global Business Managment and Research, 1(2), 1-13.

Warsanga, W. B. (2014). Coordination and Structure of Agri-Food Value Chains: Analysis of Banana Value Chain Strands in Tanzania. Journal of Economic and Sustainble Development, 5(7), 71-78.

Wiesner, R., McDonald, J., \& Banham, H. C. (2007). Australian small and medium sized enterprises (SMEs): A study of high performance management practices. Journal of Management \& Organization, 13(3), 227-248. https://doi.org/10.1017/S1833367200003710
Yasa, I. N. A., \& Hadayani. (2017). Analisis produksi dan pendapatan usahatani padi sawah di desa bonemarawa kecamatan riopakava kabupaten donggala. Agrotekbis, 5(1), 111118 .

Yun, JinHyo J. dan Jung, Young J. JeongHo, Y. (2009). Knowledge Strategy and Business Model Conditions for Sustainable Growth of SMEs. Journal Of Sciece Dan Technology Policy Management, 6(3), 246-262. https://doi.org/http://dx.doi.org/10.1108/JEIM -07-2014-0077

Zakaria, W. A. (2009). Penguatan Kelembagaan Kelompok Tani Kunci Kesejahteraan Petani. Dinamika Pembangunan Pertanian Dan Perdesaan: Tantangan Dan Peluang Bagi Peningkatan Kesejahteraan Petani" 2009, 295315. 
This page is intentionally left blank 